DEPARTMENT OF THE INTERIOR

UNITED STATES GEOLOGICAL SURVEY

\title{
MINERAL RESOURCES OF THE SHELDON CONTIGUOUS WILDERNESS STUDY AREA, WASHOE COUNTY, NEVADA
}

B y

Joel R. Bergquist ${ }^{1}$ and Donald Plouff ${ }^{1}$

U.S. Geological Survey

and

Leon R. Esparza ${ }^{2}$

U.S. Bureau of Mines

U.S. Geological Survey Open-File Report 88-246

Prepared by the U.S. Geological Survey and the U.S. Bureau of Mines
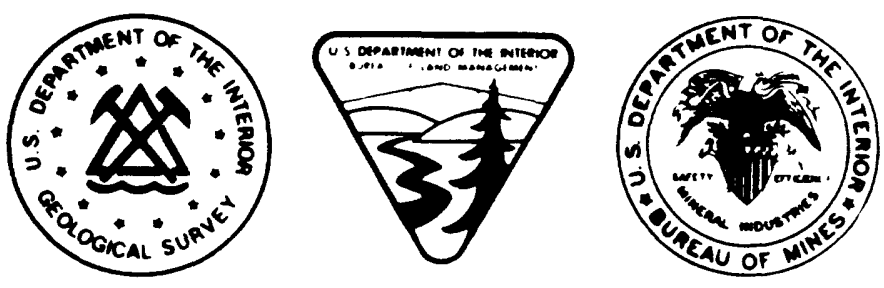

for the U.S. Bureau of Land Management

This report is preliminary and has not been reviewed for conformity with U.S. Geological Survey editorial standards and stratigraphic nomenclature. Any use of trade names is for descriptive purposes only and does not imply endorsement by the U.S. Geological Survey.

${ }^{1}$ Menlo Park, CA 94025

${ }^{2}$ Spokane, WA 99202 


\section{CONTENTS}

Summary 1

Abstract 1

Character and setting 1

Identified resources 5

Mineral resource potential 5

Introduction $\mathbf{5}$

Area description $\mathbf{5}$

Previous investigations 6

Present investigations 6

Acknowledgments 7

Appraisal of identified resources 7

Assessment of mineral resource potential 7

Geology 7

Geochemical studies 8

Geophysical studies 8

Mineral resource potential 9

References cited 9

Appendixes

Definition of levels of mineral resource potential, and certainty of assessment 12

Resource/reserve classification 13

Geologic time chart 14

\section{FIGURES}

1. Index map showing location of the Sheldon Contiguous Wilderness Study Area, Washoe County, Nevada 2

2. Map showing mineral resource potential and generalized geology of the Sheldon Contiguous Wilderness Study Area, Washoe County, Nevada 3 


\title{
MINERAL RESOURCES OF THE SHELDON CONTIGUOUS WILDERNESS STUDY AREA, WASHOE COUNTY, NEVADA
}

\author{
by Joel R. Bergquist and Donald Plouff \\ U.S. Geological Survey
}

Leon E. Esparza

U.S. Bureau of Mines

\section{SUMMARY}

\begin{abstract}
The part of the Sheldon Contiguous Wilderness Study Area (CA-020-1012) requested for mineral surveys encompasses 780 acres in the high desert of northwestern Nevada. Geological, geochemical, geophysical, and mineral surveys were conducted by the U.S. Geological Survey and the U.S. Bureau of Mines in 1985 to assess the mineral resources (known) and mineral resource potential (undiscovered) of the study area. There are no identified resources within the study area. There is low potential for undiscovered gas resources and low potential for mercury, gold, and silver resources beneath the basalt. Basalt overlies the entire study area and has a number of commercial uses, but it is not classified as a resource because basalt is abundant in the region and other sources are closer to existing markets. In this report, references to the "Sheldon Contiguous Wilderness Study Area" or the "study area" refer only to lands for which mineral surveys were requested by the U.S. Bureau of Land Management.
\end{abstract}

\section{Character and Setting}

The Sheldon Contiguous Wilderness Study Area is in northwest Nevada about $5 \mathrm{mi}$ south of the Oregon border and $20 \mathrm{mi}$ east of the California border (fig. 1). The study area is in a transitional region between the Basin and Range and the Columbia Plateau physiographic provinces and is covered by Cenozoic (see appendixes for geologic time chart) volcanic rocks (fig. 2). The surrounding area is broken by sets of predominantly northwest-trending high-angle normal faults that have shaped the terrain into flat-topped, tilted fault blocks bounded by steep fault scarps. The study area, which slopes gently toward the east, has about 200 $\mathrm{ft}$ of relief. The southern part of the study area includes the northern vertex of a flatiron, a $130-\mathrm{ft}$ high block bounded by two steep, intersecting normal-fault scarps. The southern part of the area is accessible by an unpaved road from Nevada Highway 34, and the northern part is accessible by unpaved roads between Nevada Highway 140 and the south end of Guano Valley.

The entire study area is underlain by basalt of Miocene age which weathers to a dark-gray or black color and forms a bouldery surface. There is no evidence of mining or prospecting in the study area. The nearest prospecting in the region 


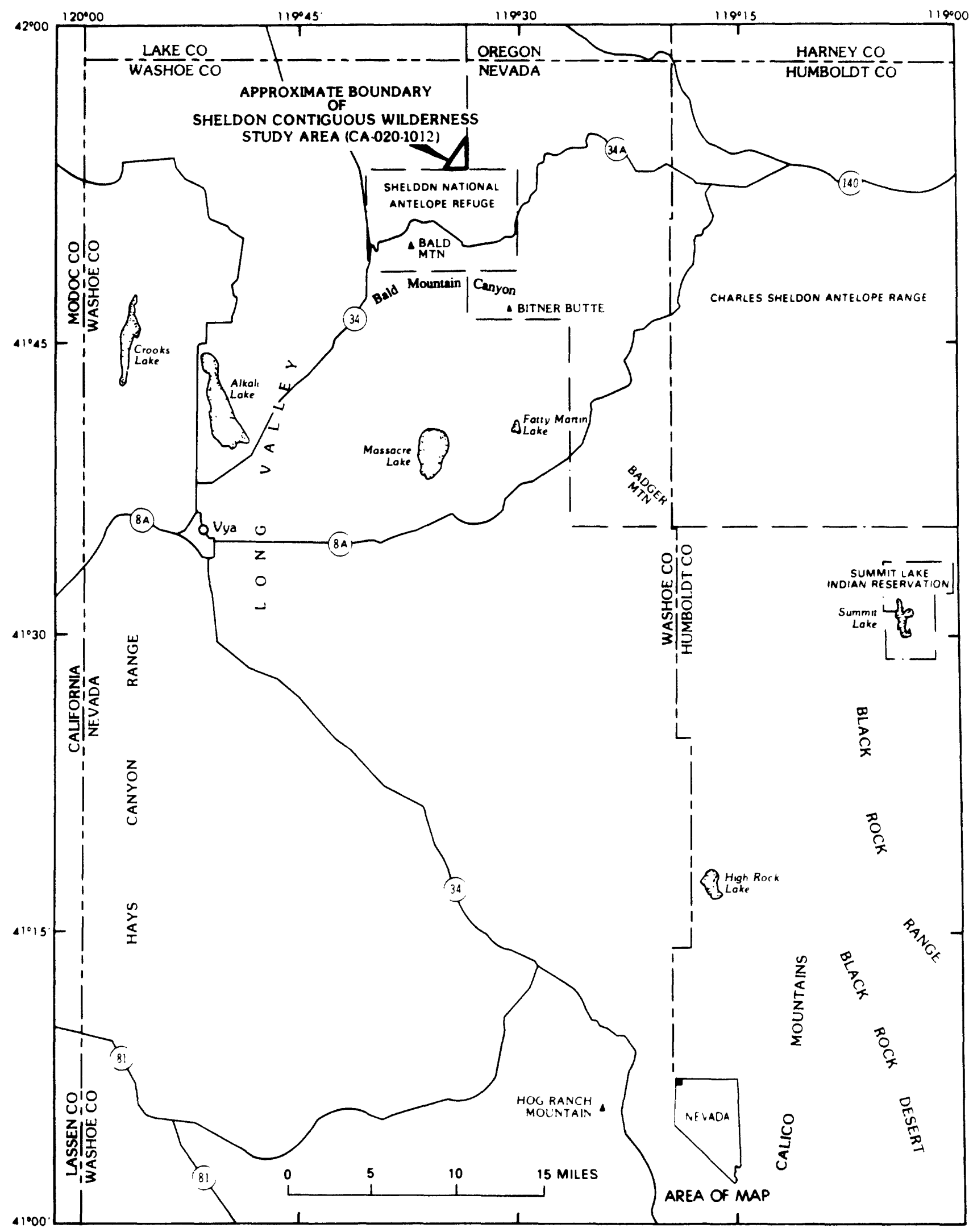

Figure 1. Index map of the Sheldon Contiguous Wilderness Study Area, Washoe County, Nevada. 


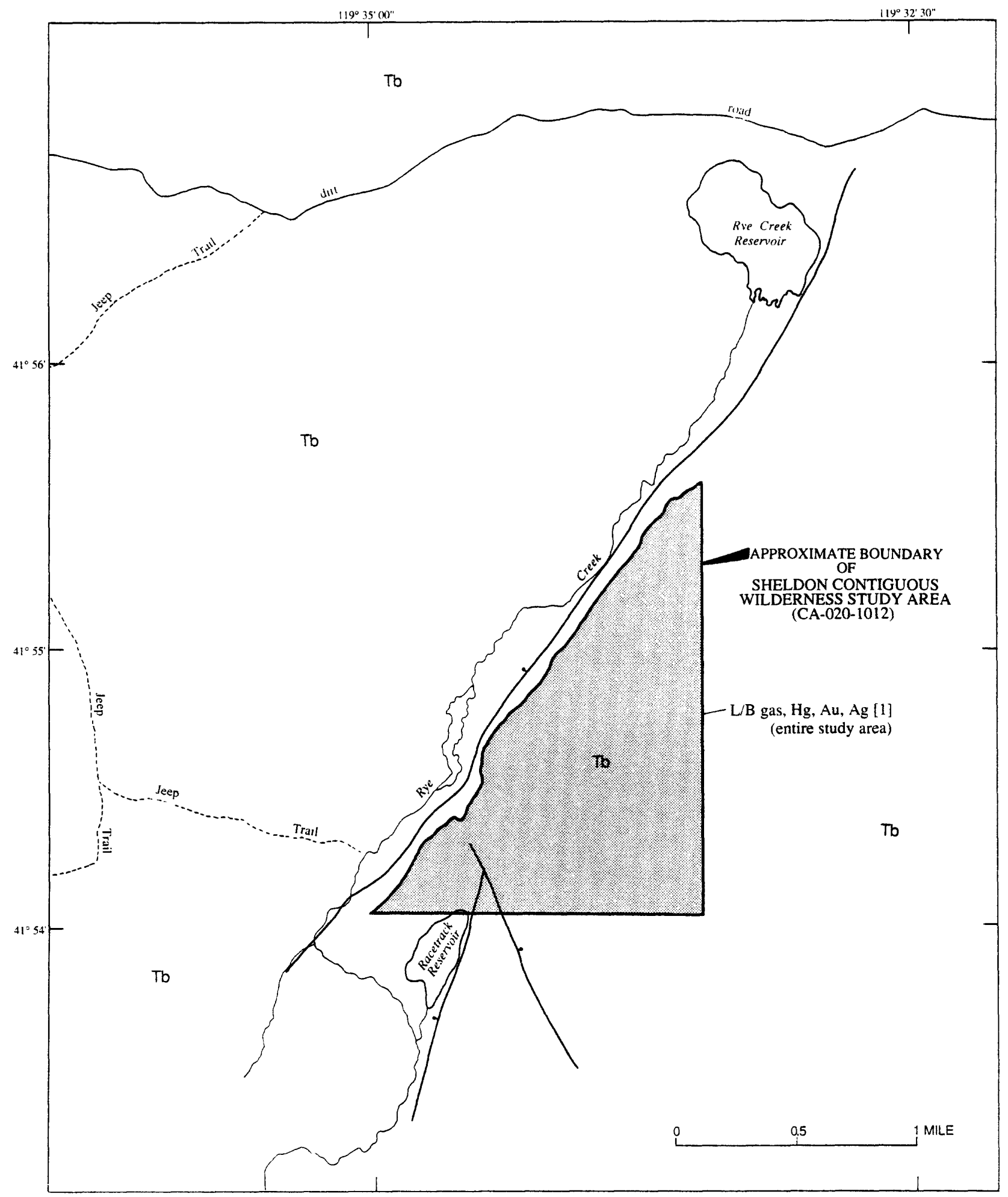

Figure 2. Mineral resource potential and generalized geologic map of the Sheldon Contiguous Wilderness Study Area, County, Nevada. 


\section{EXPLANATION}

Area having low mineral resource potential (L); data only suggest certainty of assessment (B)

Commodities
$\mathrm{Ag} \quad$ Silver
Au Gold
$\mathrm{Hg}$ Mercury
Gas
[ ] Type of deposit or occurrence
$1 \quad$ Hot spring mercury, gold, and silver
Description of map unit

Tb Basalt of Catnip Creek of Greene (1984)

(Miocene)-Brownish black- to black-

weathering basalt flows; dark to medium

grey on fresh surfaces; individual flows

typically 10 to $20 \mathrm{ft}$ thick; locally vesicular to scoriaceous

- - Fault-Dashed where approximately located.

Bar and ball on downthrown side

Figure 2. Continued 
was for gold, silver, and mercury in Bald Mountain Canyon in the Lone Pine mining district about $6 \mathrm{mi}$ south of the study area (fig. 1).

\section{Identified Resources}

There are no identified resources in the Sheldon Contiguous Wilderness Study Area.

\section{Mineral Resource Potential}

Geological, geochemical, and geophysical studies revealed no evidence of alteration, mineralization, or anomalies that would indicate the presence of undiscovered mineral deposits. However, on the basis of possible rock types at depth, the study area is determined to have low potential for gas resources and low potential for mercury, gold, and silver resources beneath the basalt.

\section{INTRODUCTION}

This mineral evaluation was requested by the U.S. Bureau of Land Management and is the result of a cooperative effort by the U.S. Geological Survey and the U.S. Bureau of Mines. The U.S. Bureau of Mines evaluates identified resources at individual mines and known mineralized areas by collecting data on current and past mining activities and through field examination of mines, prospects, claims, and mineralized areas. Identified resources are classified according to the system described by U.S. Bureau of Mines and U.S. Geological Survey (1980). Studies by the U.S. Geological Survey are designed to provide a reasonable scientific basis for assessing the potential for undiscovered mineral resources by determining geologic units and structures, possible environments of mineral deposition, presence of geochemical and geophysical anomalies, and applicable ore-deposit models. Mineral assessment methodology and terminology related to these surveys were discussed by Goudarzi (1984). See appendixes for the definition of levels of mineral resource potential and certainty of assessment and for the resource/reserve classification.

\section{Area Description}

The part of the Sheldon Contiguous Wilderness Study Area (CA-020-1012) for which mineral surveys were requested encompasses 780 acres in Washoe County, Nev., about $5 \mathrm{mi}$ south of the Oregon border (fig. 1). The region is characterized by flat-topped, tilted fault blocks of basalt, fault-bounded flatirons, and steep fault scarps. The study area is shaped like a right triangle having a 2 mi-long hypotenuse on the northwest side (fig. 2). The northwest boundary is located along a steep fault scarp, but the study area itself is fairly flat and slopes gently to the southeast. The surface of the area is bouldery, and there is little soil. Elevations range from $5,620 \mathrm{ft}$ at the bottom of a drainage on the east side of the study area to $5,844 \mathrm{ft}$ at the highest point on the west side of the study area at 
the top of the steep, $300-\mathrm{ft}$ fault scarp. There are several small ephemeral lakes within about $1 \mathrm{mi}$ of the study area, and one of these drains through the southeast corner of the study area. The northern part of Racetrack Reservoir is also within the study area. Rye Creek, an intermittent stream, flows northeast along the base of the fault scarp that forms the northwestern boundary of the study area. Vegetation consists of grasses, sagebrush, and scattered pinyon and juniper. The region supports a diverse fauna of antelope, deer, small mammals, sage grouse, and raptorial birds. The climate is arid to semi-arid high desert and has an average annual precipitation of 8 to 16 in. including about $4 \mathrm{ft}$ of snow (Houghton and others, 1975).

\section{Previous Investigations}

Bonham (1969) describes the geology and mineral deposits of Washoe County and includes a geologic map at a scale of 1:250,000. A report on the Sheldon Wilderness Study Area by the U.S. Geological Survey and U.S. Bureau of Mines (1984) comprises the following four articles that include information pertaining to this mineral assessment. Greene (1984) discusses the geology of the region and includes a geologic map of the Charles Sheldon Antelope Range, the Sheldon National Antelope Refuge, and adjacent areas at a scale of 1:125,000. Plouff (1984) interprets the aeromagnetic and gravity data for the region. Cathrall and others (1984) give the geochemical evaluation of mineral and geothermal resources of the Sheldon Wilderness Study Area. Tuchek and others (1984) present the economic appraisal of the Sheldon Wilderness Study Area. A draft environmental impact statement was published by U.S. Bureau of Land Management (1984).

\section{Present Investigations}

The U.S. Geological Survey conducted field investigations in the summer of 1985. Work consisted of geologic mapping and geochemical sampling. Geochemical samples were collected in order to obtain information about mineral suites and trace-element signatures, which can indicate mineralized areas. These samples were analyzed by semiquantitative spectrographic and atomic absorption methods.

The U.S. Bureau of Mines study was carried out in the late Spring of 1985. Geological libraries, U.S. Bureau of Mines records, and the Mineral Industry Location System (MILS) were searched for information on mines and prospects in and around the study area. The U.S. Bureau of Mines also conducted an examination of U.S. Bureau of Land Management mining-claim records, land status records, and Washoe County, Nev., mining-claim records. The field study consisted of a search for mines, prospects, and mineralized areas. Four rock samples were collected and analyzed for 40 elements by semiquantitative spectrographic methods (Esparza, 1986). Complete analytical data are on file at the U.S. Bureau of Mines, Western Field Operations Center, Spokane, WA 99202. 


\section{Acknowledgments}

Joseph McFarlan and other members of the Cedarville, Calif., District Office of the U.S. Bureau of Land Management provided help and the use of Stevens Camp. Dr. Donald C. Noble of the University of Nevada, Reno, led an informative field trip through the region for Bureau of Land Management and U.S. Geological Survey personnel.

\section{APPRAISAL OF IDENTIFIED RESOURCES}

\section{By Leon E. Esparza}

\section{U.S. Bureau of Mines}

There are no known mines, prospects, claims, or mineral leases in the wilderness study area. There is no evidence of previous mining or exploration in the study area, and there is no history of mining in the immediate vicinity. The nearest active mineral exploration (1985) is for gold, about $6 \mathrm{mi}$ south of the study area in Bald Mountain Canyon in the Lone Pine Mining District. No evidence of mineralization was observed in the study area. On the basis of field observations and laboratory analyses, no mineral deposits were identified in the study area.

There are no identified resources in the study area. Basalt can be used for aggregate, fill, building stone, road metal, lining material, industrial flooring, or processed for fiber optic applications. However, the basalt in this study area is not classified as a resource because it is abundant in the region, and other sources are more accessible and closer to existing markets.

\section{ASSESSMENT OF MINERAL RESOURCE POTENTIAL}

By Joel R. Bergquist and Donald Plouff

U.S. Geological Survey

\section{Geology}

The Basalt of Catnip Creek of Miocene age (Greene, 1984, p. 29) forms the bedrock of the study area and surrounding areas. The basalt consists of numerous thin flows (10-20 ft thick) that comprise a minimum of $300 \mathrm{ft}$ in aggregate thickness, based on measurements of fault scarps. Greene (1984) reports a continuous sequence of 24 basalt flows in a nearly vertical fault scarp at Racetrack Reservoir south of the study area. The basaltic lavas were erupted from numerous vents and fissures in the region, none of which are known to occur within the study area. Columnar jointing was observed in the flows exposed at Racetrack Reservoir. The basalt is dark to medium gray on fresh surfaces, finegrained to aphanitic, and contains 25-60 percent plagioclase, 7-30 percent olivine, 12-50 percent clinopyroxene, 2-12 percent magnetite, and 1-10 percent voids between plagioclase crystals (Greene, 1984, p. 29). Olivine and plagioclase 
microphenocrysts locally make up as much as a few percent of the basalt (Greene, 1984), but the rock is typically equigranular. The basalt weathers to brownish black or black. Tops and bottoms of flows are vesicular to scoriaceous, and the bottoms of flows locally include alloclastic breccia. The structure of the region is dominated by conjugate sets of normal faults that trend northeast and northwest (the predominant direction). The faulting reflects post-Oligocene tectonic extension in the Basin and Range province. Vertical displacements along these high-angle normal faults are about $300 \mathrm{ft}$ at the north end of the study area and about $130 \mathrm{ft}$ at Racetrack Reservoir.

The nearest prospecting in the region has been about $6 \mathrm{mi}$ south of the study area, in the Lone Pine district which is centered in Bald Mountain Canyon. Mercury is the primary commodity, and it occurs as cinnabar in veinlets, stringers, and disseminations along fracture zones in silicified and argillized Miocene andesite (Bonham, 1969). These deposits are the hot-spring mercury type described by Rytuba (1986). Prospecting for gold and associated silver in hot-spring deposits (see Berger, 1986) has also been done in Bald Mountain Canyon, but there are no records of any production. In Bald Mountain Canyon, the rocks consist of Lower(?) Miocene tuff and altered porphyritic andesite that are older than the Basalt of Catnip Creek that underlies the study area. Rocks like those in Bald Mountain Canyon may be present beneath the basalt in the study area, but this cannot be determined from existing data.

\section{Geochemical Studies}

The U.S. Geological Survey collected four rock samples from the wilderness study area. These were analyzed by atomic absorption techniques for gold and for 31 elements using a six-step semiquantitative emission spectrographic method described by Grimes and Marranzino (1968). No anomalous concentrations of elements were detected in the rock samples (Robert L. Turner, U.S. Geological Survey, unpub. data, 1986), and the geochemical data give no indications of mineralization in the study area.

\section{Geophysical Studies}

The geophysical evaluation of the study area is based on an interpretation of the gravity and magnetic maps prepared for the mineral resource study of the Sheldon Wilderness Study Area (U.S. Geological Survey and U.S. Bureau of Mines, 1984, pl. 2; Plouff, 1984). The gravity data coverage consists of one station near Racetrack Reservoir $0.2 \mathrm{mi}$ southwest of the study area and a ring of 11 stations at distances of 2 to $4 \mathrm{mi}$ from the study area. The gravity map shows a gradient of 1 to $2 \mathrm{mGal} / \mathrm{mi}$, with lower values toward the northeast corner of the study area. The data coverage is too sparse to indicate if a gravity minimum is reached within the study area or to correlate the gravity map with the pattern of block faulting.

An aeromagnetic map was contoured from data collected at a constant barometric elevation of $9,000 \mathrm{ft}$ along flightlines spaced at 2 -mi intervals. The 
study area is located along the southwest edge of a magnetic high centered $1 \mathrm{mi}$ northeast of the study area. The magnetic high forms a local high with an amplitude of about 100 nanoteslas (nT), and is part of a larger northeast-trending magnetic high with an amplitude of about $300 \mathrm{nT}$. Plouff (1984) suggested that the magnetic highs may reflect a volcanic center with rocks of moderate magnetization concealed beneath a veneer of basalt that has low magnetization. The gravity data listed by Plouff and others (1976) reveal that a 3-mGal gravity high, centered about $2 \mathrm{mi}$ northeast of the study area, nearly coincides with the smaller aeromagnetic high.

\section{Mineral Resource Potential}

There are no identified resources in the Sheldon Contiguous Wilderness Study Area, and there are no indications of alteration, mineralization, or geochemical and geophysical anomalies that might indicate the presence of undiscovered mineral resources.

The nearest known mineral deposits (mercury, gold, and minor silver) are in Bald Mountain Canyon in the Lone Pine mining district about $6 \mathrm{mi}$ south of the study area. The rocks in Bald Mountain Canyon consist of Lower(?) Miocene tuff and andesite that are older than the Miocene basalt of Catnip Creek that underlies the study area. The older rocks found in Bald Mountain Canyon may extend beneath the basalt in the study area, although this is not known. On this basis, the study area is assigned low potential, certainty level B, for mercury, gold, and silver resources in hot-spring type deposits beneath the basalt. If mineral deposits similar to those in Bald Mountain Canyon (Lone Pine mining district) do exist within the study area, the thickness of the overlying basalt (a minimum of about $300 \mathrm{ft}$ ) probably would make their discovery and exploitation difficult using present technology.

Sandberg (1983) evaluated the petroleum potential of Nevada and concluded that the region that includes the Sheldon Contiguous Wilderness Study has "zero potential" for petroleum. The geology beneath the basalt in the study area is unknown, but it is possible that there are lake beds or alluvial sequences that may contain gas. Therefore, the study area is assigned a low potential, certainty level $\mathrm{B}$, for gas resources.

\section{REFERENCES CITED}

Berger, B.R., 1986, Descriptive model of hot-spring Au-Ag, in Cox, D.P., and Singer, D.A., eds., Mineral deposit models: U.S. Geological Survey Bulletin 1693, p. 143-144.

Bonham, H.F., 1969, Geology and mineral deposits of Washoe and Storey Counties, Nevada, with a section on Industrial rock and mineral deposits by K.G. Papke: Nevada Bureau of Mines and Geology Bulletin 70, 140 p. 
Cathrall, J.B., Siems, D.F., Crenshaw, G.L., and Cooley, E.F., 1984, Geochemical evaluation of the mineral and geothermal resources of the Sheldon Wilderness Study Area, Nevada and Oregon: U.S. Geological Survey Bulletin 1538-C, p. 51-88.

Esparza, L.E., 1986, Mineral resources of the Sheldon Contiguous Study Area, Washoe County, Nevada: U.S. Bureau of Mines Mineral Land Assessment Open-File Report 31-86, 9 p.

Goudarzi, G.H., 1984, Guide to preparation of mineral reports on public lands: U.S. Geological Survey Open-File Report 84-787, 51 p.

Greene, R.C., 1984, Geologic appraisal of the Sheldon Wilderness Study Area, Nevada: U.S. Geological Survey Bulletin 1538-A, p. 13-34.

Grimes, D.J., and Marranzino, A.P., 1968, Direct-current arc and alternatingcurrent spark emission spectrographic field methods for the semiquantitative analysis of geologic materials: U.S. Geological Survey Circular 591, 6 p.

Houghton, J.G., Sakamoto, C.M., and Gifford, R.O., 1975, Nevada's weather and climate: Nevada Bureau of Mines and Geology Special Publication 2, 78 p.

Plouff, Donald, 1984, Interpretation of aeromagnetic and gravity data, Sheldon Wilderness Study Area, Nevada and Oregon: U.S. Geological Survey Bulletin 1538-B, p. 35-50.

Plouff, Donald, Robbins, S.L., and Holden, K.D., 1976, Principal facts for gravity observations in the Charles Sheldon Antelope Range, Nevada-Oregon: U.S. Geological Survey Open-File Report 76-601, 22 p.

Rytuba, J.J., 1986, Descriptive model of hot-spring Hg, in Cox, D.P., and Singer, D.A., eds., Mineral deposit models: U.S. Geological Survey Bulletin 1693, p. 178179.

Sandberg, C.A., 1983, Petroleum potential of wilderness lands in Nevada, in Miller, B.M., ed., Petroleum potential of wilderness lands in the western United States: U.S. Geological Survey Circular 902-H, p. H1-H11.

Tuchek, E.T., Johnson, F.J., and Conyac, M.D., 1984, Economic appraisal of the Sheldon Wilderness Study Area, Nevada and Oregon: U.S. Geological Survey Bulletin 1538-D, p. 89-139.

U.S. Bureau of Land Management, 1984, WSA CA-020-1012, Sheldon Contiguous, in Chapter 3 of Preliminary wilderness recommendations, Eagle Lake-Cedarville study area, draft environmental impact statement: U.S. Bureau of Land Management, Susanville District Office, Calif., p. 3-91 to 3-96.

U.S. Bureau of Mines and U.S. Geological Survey, 1980, Principles of a resource/reserve classification for minerals: U.S. Geological Survey Circular $831,5 \mathrm{p}$.

U.S. Geological Survey and U.S. Bureau of Mines, 1984, Mineral resources of the Sheldon Wilderness Study Area, Humboldt and Washoe Counties, Nevada, and Lake and Harney Counties, Oregon: U.S. Geological Survey Bulletin 1538, 139 p., 2 pl., scale 1:125,000. 


\section{APPENDIXES}




\section{DEFINITION OF LEVELS OF MINERAL RESOURCE POTENTIAL AND CERTAINTY OF ASSESSMENT}

LOW mineral resource potential is assigned to areas where geologic, geochemical, and geophysical characteristics define a geologic environment in which the existence of resources is permissive. This broad category embraces areas with dispersed but insignificantly mineralized rock as well as areas with few or no indications of having been mineralized.

MODERATE mineral resource potential is assigned to areas where geologic, geochemical, and geophysical characteristics indicate a geologic environment favorable for resource occurrence, where interpretations of data indicate reasonable likelihood of resource accumulation, and (or) where an application of mineral-deposit models indicates favorable ground for the specified type(s) of deposits.

HIGH mineral resource potential is assigned to areas where geologic, geochemical, and geophysical characteristics indicate a geologic environment favorable for resource occurence, where interpretations of data indicate a high degree of likelihood for resource accumulation, where data supports mineral-deposit models indicating presence of resources, and where evidence indicates that mineral concentration has taken place. Assignment of high resource potential to an area requires some positive knowledge that mineral-forming processes have been active in at least part of the area.

UNKNOWN mineral resource potential is assigned to areas where information is inadequate to assign low, moderate, or high levels of resource potential.

NO mineral resource potential is a category reserved for a specific type of resource in a well-defined arca.

Levels of Certainty

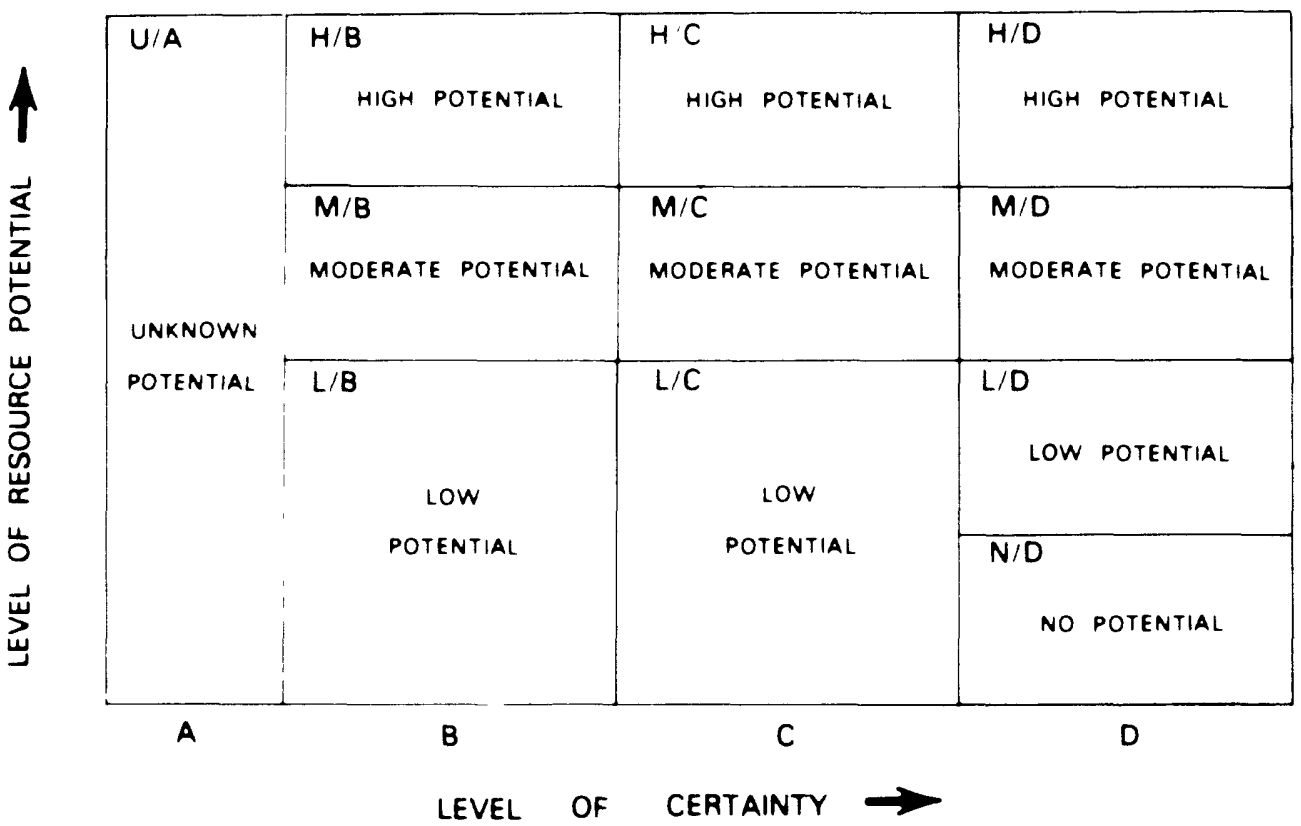

A. Avallable information is not adequate for determination of the level of mineral resource petential

$B$ Avalable information suggests the level of mineral resource potential

C Available information gives a good indication of the level of mineral resource potential

D. Available information clearly defines the level of mineral resource potential

Abstracted with minor modifications from:

Taylor, R B , and Steven. T A.. 198.3. Defintion of mineral resource potential: Economic Geology. $\checkmark 78$, no $6, \mathrm{p} 1268 \quad 1270$

Taylor. R B. Stoneman. R J., and Marsh, S P . 1984. An assessment of the mineral resource potential of the San lsabel National Forest, south-central Colorado. U S Geological Survey Bulletin 16.38, $p$ 40.42

Goudarı. G H.. compiler, 1984. Guide to preparation of mineral survey reports on public lands. U.S Geological Survey Open-File Report 84 17787. p 7.8 


\section{RESOURCE/RESERVE CLASSIFICATION}

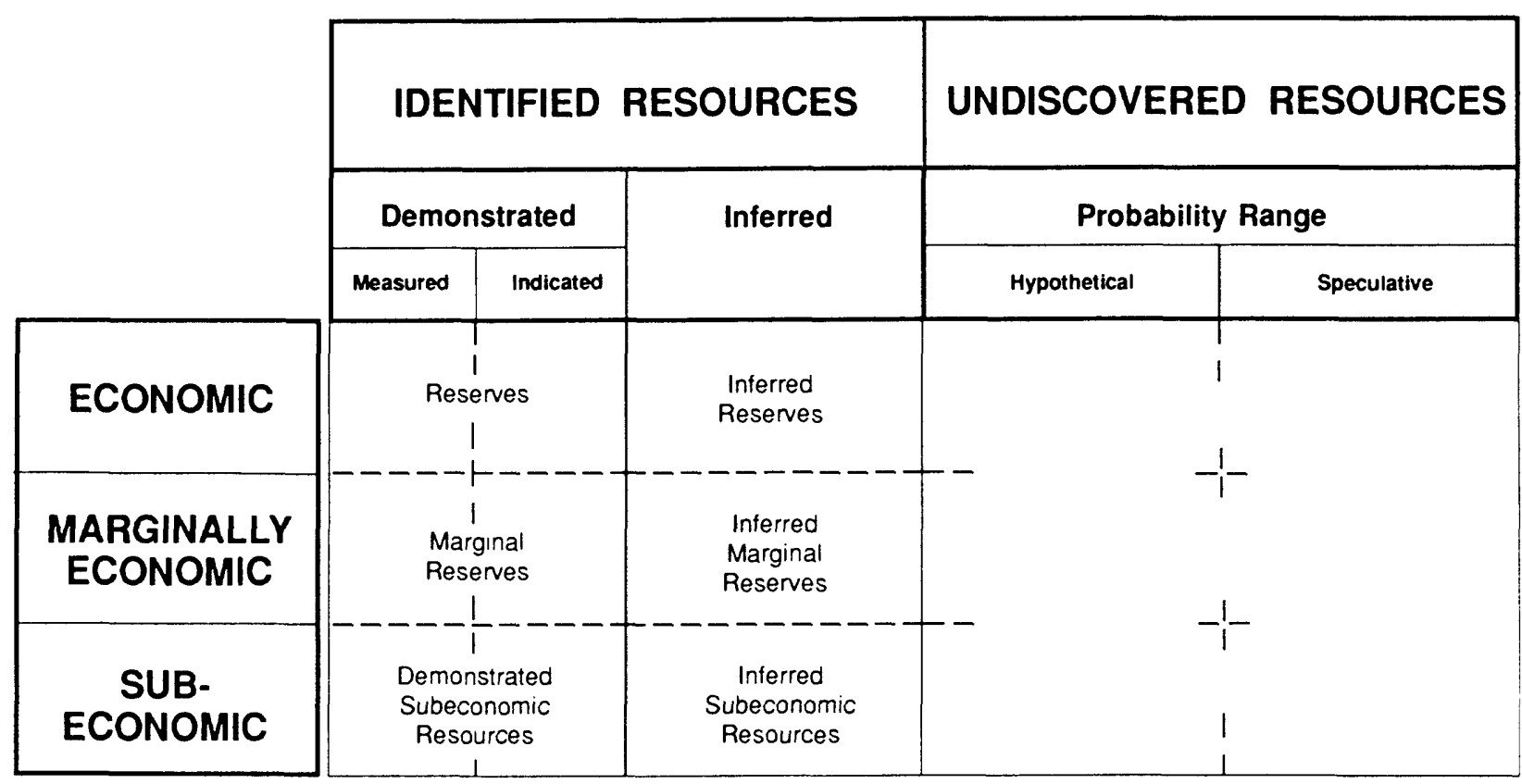

Major elements of mineral resource classification, excluding reserve base and inferred reserve base. Modified from V.E. Mckelvey, 1972, Mineral resource estimates and public policy: American Scientist, v. $60, p .32-40$, and U.S. Bureau of Mines and

U.S. Geological Survey, 1980, Principles of a resource/reserve classification for minerals: U.S. Geological Survey Circular 831, p. 5 . 
GEOLOGIC TIME CHART

Terms and boundary ages used by the U.S. Geological Survey in this report

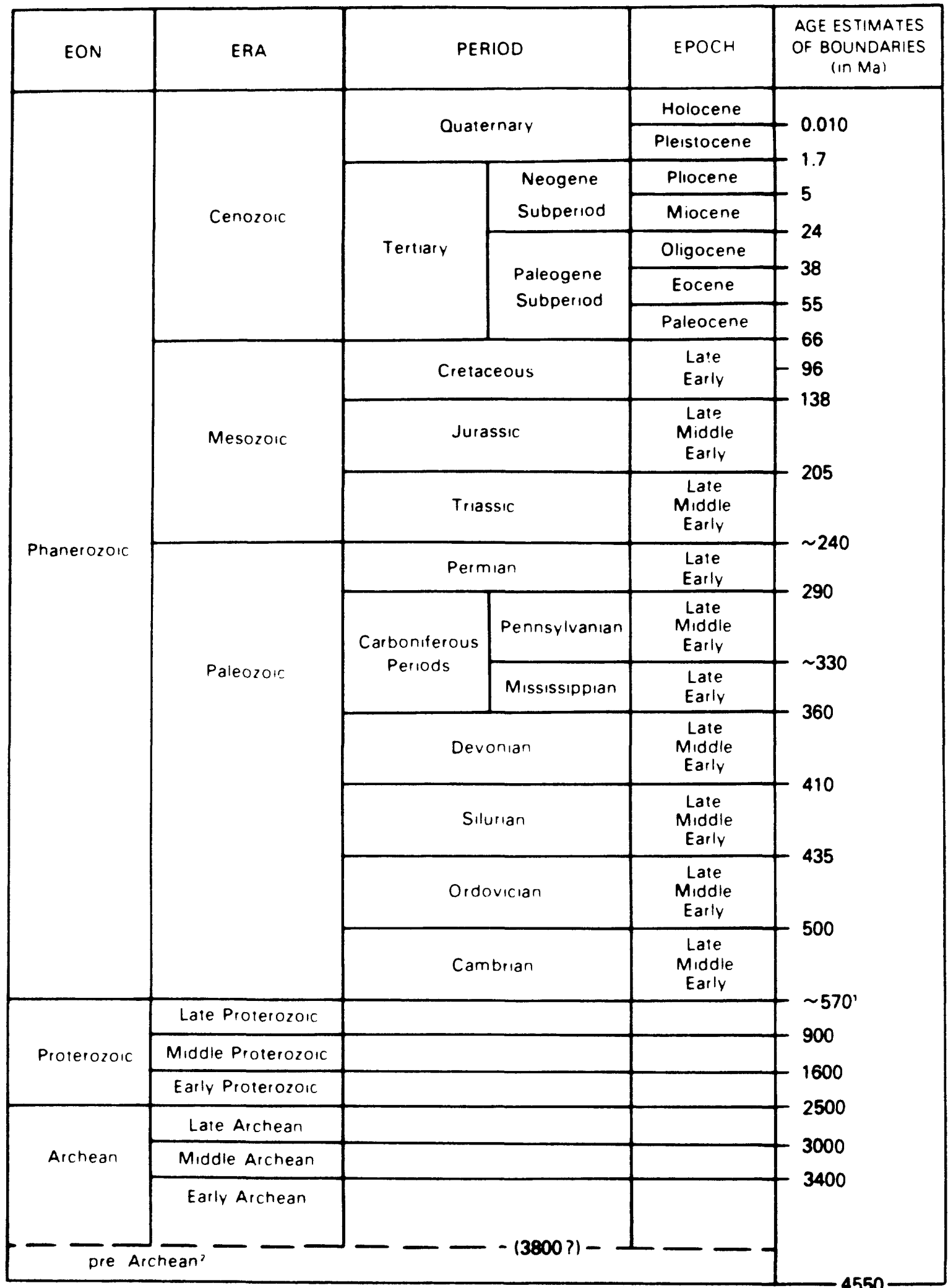

'Rocks older than 570 Ma also called Precambrian, a time term without specific rank

'Informal time term without specific rank 